\title{
Melanocortin Pathway Defect
}

National Cancer Institute

\section{Source}

National Cancer Institute. Melanocortin Pathway Defect. NCI Thesaurus. Code C120383.

An abnormality in the biochemical pathway involving the melanocortins, a group of peptide hormones associated with anorexogenic signaling in the brain and hypothalamus. 